See discussions, stats, and author profiles for this publication at: https://www.researchgate.net/publication/334150701

\title{
Los viajeros están de viaje: Turismo, memoria y la experiencia cultural del viaje
}

Preprint · July 2019

DOI: $10.13140 / R G .2 \cdot 2.15334 .47685$

CITATIONS

2 authors:

Fabián Andrés Llano

11 Universitaria uniagustiniana

68 PUBLICATIONS 55 CITATIONS

SEE PROFILE
READS

176

Giovanny Enrique Araque Suárez

Corporación Unificada Nacional de Educacion Superior

14 PUBLICATIONS 6 CITATIONS

SEE PROFILE

Some of the authors of this publication are also working on these related projects:

TURISMO DE MEMORIA Y POSTCONFLICTO: CULTURAS DEL RECUERDO ALREDEDOR DE LAS TERTULIAS, COMIDAS Y BEBIDAS EN EL OCASO DE LA ATENAS SURAMERICANA (1910-1950) View project

Historia cultural de Bogotá View project 


\title{
Los viajeros están de viaje: \\ Turismo, memoria y la experiencia cultural del viaje ${ }^{1}$
}

\author{
Fabián Andrés Llano \\ Giovanny Araque Suarez ${ }^{3}$
}

\section{Introducción}

Las diferentes representaciones y las imágenes que se asocian al descubrimiento de Auschwitz entre enero y abril de 1945 han pretendido explicar el acontecimiento que dejó en shock al mundo. Además de la producción de libros y material probatorio, aparece la imagen como elemento fundamental para la condena de los nazis. De acuerdo con Sánchez (2004) el afán de combatir cualquier denegación del crimen llevó a cineastas como Sydney Berstein, Alfred Hitchcock y el montador Peter Tanner a ordenar y dar forma de película a los abundantes rollos rodados a la entrada de los campos de concentración. Estos montajes permitieron el intercambio de imágenes con cineastas como George C. Stevens quien poseía las imágenes recolectadas por el servicio americano de crímenes. Según este mismo autor, en este contexto prosperó una idea asociada a una especie de pedagogía del horror que empezó a difuminarse bajo la urgencia testimonial para dar a conocer la barbarie por medios visuales. Bajo las exigencias de documentación y las necesidades jurídicas de la inculpación,

\footnotetext{
${ }^{1}$ El presente capítulo hace parte de los resultados de investigación del proyecto titulado: Turismo de memoria y posconflicto. Este proyecto ha sido financiado por la Corporación Unificada Nacional de Educación Superior CUN durante el año 2018 y continúa su segunda fase en el presente año (2019).

2 Doctorando en Ciencias Humanas del Patrimonio y la Cultura Universidad de Girona (España) Magister en Investigación social interdisciplinaria de la Universidad Distrital Francisco José de Caldas, Licenciado en Ciencias Sociales. En la actualidad se desempeña como docente investigador del programa Administración Turística y Hotelera Corporación Unificada Nacional de educación superior CUN fabian-llano@upc.edu.co, fabian_llano@cun.edu.co llanofabian@ @otmail.com ID 0000-0003-2181-3476

${ }^{3}$ Magister en Desarrollo Educativo y Social CINDE-UPN, Licenciado en Ciencias Sociales Universidad Distrital Francisco José de Caldas. Miembro del Consejo de redacción de los periódicos Le monde diplomatique edición Colombia y desde abajo. Docente-investigador del programa Administración Turística y Hotelera, Corporación Unificada Nacional de educación superior CUN. Miembro del Grupo de Investigación Desarrollo y Crecimiento Económico Regional GIDECER. blogotano@yahoo.es ; giovanny_araque@cun.edu.co. ID 0000-0002-8562-4431
} 
se hizo evidente una directriz autentificadora que consistía en dejar que las imágenes hablaran por si mismas con el propósito de convertirlas en las pruebas en contra de los crímenes nazis.

De otro lado, la referencia a Francis Boix, fotógrafo español miembro de las Juventudes Socialistas Unificadas de Cataluña (JSUC) representa otra experiencia similar referida ahora al campo de concentración de Mauthausen. En plena dictadura franquista Francis Boix, partió a Francia para lograr escapar de las persecuciones a las $\mathrm{JSUC}^{4}$; allí fue capturado por los nazis en 1940 y deportado al campo de concentración de Mauthausen donde permaneció por cuatro años y tres meses hasta su liberación en mayo de 1945. La historia de Boix resulta relevante en cuanto representa una lucha por mantener el deber de memoria mediante una resistencia al olvido. Como ayudante de fotografía, Boix fue designado para colaborar en el laboratorio de fotografía del mencionado campo de concentración, donde fue testigo junto con su cámara Leica de atrocidades contra la dignidad humana.

Parte de su resistencia consistió en guardar los negativos que circularon por el laboratorio, de algunas fotografías macabras que posteriormente podrían inculpar a algunos miembros de las fuerzas nazis. Aunque el caso ha sido documentado en algunos libros y reportajes periodísticos, también ha sido difundido a través del cine. La experiencia de Boix, ahora referenciada con la película el fotógrafo de Mauthausen de la directora Mar Taragona, se convierte en otra forma de difusión del genocidio. En este film se muestra que parte de la resistencia de Boix consistió en la recolección de negativos fotográficos escondidos en el campo de concentración durante su reclusión. De acuerdo con la narrativa cinematográfica, los negativos fotográficos convertidos en archivos y testimonios, fueron custodiados por una red de apoyo que arriesgó su vida para sacar los archivos del campo de concentración y de esta manera mantener la esperanza de difundir posteriormente el horror allí vivido. Para corroborar que todo ese esfuerzo no quedara en la impunidad y en olvido, en la narración de

\footnotetext{
${ }^{4}$ De acuerdo con Casterás (s.f) las Juventudes Socialistas de la «Unión Socialista», el pequeño grupo de las Juventudes del «Partit Cátala Proletari» que no se llegó a integrar en «Estat Cátala», las Juventudes Comunistas del Partido Comunista de España y la Federación Catalana de las Juventudes Socialistas de España. Todas ellas constituirían en 1936 las Juventudes Socialistas Unificadas de Cataluña homologables a las JSU de España. Y junto a todas estas organizaciones, adscritas a unos determinados partidos políticos, pero con capacidad crítica e incluso rupturista, existieron las Juventudes del Bloque Obrero y Campesino y las Juventudes de Izquierda Comunista que en 1936 y con vocación peninsular, conformaron también las denominadas Juventudes Comunistas Ibéricas del POUM
} 
la película aparecen al final del film las fotografías reveladas de lo sucedido en Mauthausen, junto con algunas imágenes que dan cuenta del testimonio de Boix con el develamiento de su archivo fotográfico en el juicio de Nurenberg, acusando a algunos alemanes implicados en estos hechos 5 .

Ahora bien, estas diferentes representaciones e imágenes que han circulado bajo el símbolo de Auschwitz y que además, han sido posicionadas por medio de producciones escritas y montajes cinematográficos sobre el horror, se han expandido a otros frentes de difusión que buscan promocionar la visita a estos lugares petrificados y aparentemente detenidos en la historia. Aquí resulta importante mencionar que los medios de producción y difusión como internet, el cine y las series televisivas han logrado difundir unos sentidos y significados de hechos del pasado, al convertir estos lugares desolados e imaginarios, en museos sin pared que bien pueden ser visitados y consumidos ${ }^{6}$. En estos espacios re-creados, el problema de la memoria cobra actualidad sobre la base de montajes sobre las experiencias vividas en los campos de concentración y de la promoción de lugares de memoria para un público que busca respuestas, o que requiere constatar las ficciones que ha consumido.

\footnotetext{
${ }^{5}$ En los ejemplos expuestos con anterioridad se ha mostrado la relevancia dada a la imagen. Esta importancia se puede explicar mediante algunas referencias que resultan esclarecedoras. De acuerdo con Collingwood (2012) entre el siglo XIX y parte del XX la razón histórica y la razón fotográfica encuentran cierta complicidad en el uso de la técnica como elemento que poco a poco intentará desplazar a la escritura de la historia de su sitial privilegiado. Si bien es cierto que los documentos -monumentos- que más interesan al historiador historicista siguen siendo los documentos escritos, que la escritura y la lectura-en sentido restringido-siguen siendo las tecnologías que de manera privilegiada solventan la acumulación, procesamiento, configuración y difusión del conocimiento histórico, no será en la tecnología de la escritura, sino en la de la fotografía donde la razón historicista encontrará probablemente sin saberlo y ciertamente sin reconocerlo-su soporte estructural(p93)

6 La idea de plantear un museo imaginario y un museo sin pared, en efecto, no es una idea original, proviene de los planteamientos de André Malraux, quien en la decada del cuarenta plantea la posibilidad de un museo sin limites y sin restricciones de ninguna clase. El simil se utiliza para denotar que bajo la dinámica del internet, se multiplican las posibilidades de ofertas turisticas al mostrar unos itinearios creados con una oferta complementaria muy especifica, que por lo menos, da cuenta de dos momentos en la experiencia turistica. El primer momento que se enmarca en la mirada de la ventana (internet) que introduce una relacion directa con las geografias imaginarias a las que se enfrenta el navegador. Aquí sin una aparente restricción el usuario o el turista crean un espacio vital de experiencia donde conoce virtualmente los lugares que pretende recorrer. El segundo momento es de cosntatación de esta experiencia virtual vivida en escenarios y lugares concretos. De ahí la importancia comercial de tener coherencia entre uno y otro momento de la experiencia turistica.
} 
En esta dinámica, el problema asociado a la memoria se vincula en relación con unos usos lucrativos de la memoria y la difusión de lugares de memoria ${ }^{7}$. En efecto, este constante bombardeo de imágenes y representaciones sobre la guerra, permite desplegar un mayor interés en la actividad turística en lo que se ha denominado la turistificación del pasado. Concreciones directas de este fenómeno se expresan en propuestas alternativas de turismo desplegadas en las siguientes tipificaciones: Turismo de memoria, turismo oscuro, tanatoturismo, turismo del trauma, turismo de reconciliación o turismo fénix sin dejar de lado, el turismo de lugares en conflicto, conocido como Danger Zone Tourism. Estas propuestas basadas en mayor medida en las actividades de tipo económico no solo establecen directrices que buscan autentificar y testimoniar lo ocurrido, sino difundirlo y popularizarlo.

Es por esto que, sin la mediación de un turismo responsable, los guiones interpretativos narran sin tapujos los hechos más crueles, bajo unos relatos que buscan impactar al visitante mostrándole lo que quiere ver. En una especie de simulacro y de acuerdo implícito entre el operador turístico, el guía turístico y el turista, se articula una complicidad bajo la narración de representaciones del pasado plagada de anécdotas y de imprecisiones espaciales y temporales. Bajo una planificación del viaje con los tiempos justos y unos itinerarios calcados para todos los momentos y públicos, es poco práctico una narración de corte estructural y con una profundidad importante. Lo que si resulta problemático, sobre todo para el caso de un turismo de memoria, es la promoción de la visión y la popularización del perpetrador al dejar por fuera las víctimas de los acontecimientos. Tal es el caso de los ya famosos narcotours inspirados en las series de los capos que han difundido una cartografía del crimen

\footnotetext{
${ }^{7}$ Esta referencia al concepto de lugares de memoria propuesto por Pierre Nora, plantea la imagen de un núcleo que condensa diferentes representaciones y constituye las marcas y los signos del pasado en un territorio. En este proceso de construcción de los lugares de memoria se presentan confrontaciones y la negociaciones en las formas de representación del pasado mediante proyectos de conmemoración y rememoración (Palacios, 2010). Por lo general el uso turistico de estos denominados lugares de memoria tienden a reproducir el efecto de los historicismos en la elaboracion de guiones interpretativos apegados a estos discursos sobre el pasado. Ahora bien habria que tener en cuenta las advertencias de Walter Benjamin cuando sostiene que todo documento de cultura ( ya sean textos, monumentos o cualquiere otro dispositivo), tiene su contraparte en un documento de barbarie.De acuerdo con Serna(2012) un efecto último de los historicismos lleva a que conmemorar se traduzca como dar a conocer erigiendo, por ejemplo, lugares de la memoria, esa ficción tan recurrida desde que la planteara Pierre Nora, de la que distintos autores señalan que no ha sido sino una versión edulcorante de la historia francesa que vindicaba al tour de Francia pero omitía cuestiones tan sensibles como las guerras colonialistas como la de Argelia(p72)
} 
en Medellín. En la recomendación de sicarios reconocidos y populares, se exalta el antivalor y la promoción de una especie de apología del "patrón” Pablo Escobar, en una ruta que lleva su nombre ${ }^{8}$.

Ahora bien, estas dinámicas turísticas corresponden a una diversificación de la oferta y a un creciente mercado que busca hacer de las experiencias culturales, eventos de fácil recordación y de consumo masivo. Es imposible negar el impacto y el alto crecimiento del turismo en el mundo y tampoco se puede desconocer a las agencias y las políticas públicas que buscan promocionar países, ciudades y regiones como destinos turísticos importantes. Si la Organización Mundial del Turismo promueve la idea del turismo como catalizador para la paz y el desarrollo y algunas iniciativas gubernamentales buscan fortalecer la imagen de las regiones por medio de la relación turismo y paz, entonces, cabría hacer las siguientes preguntas. Con respecto a las propuestas turísticas reafirmadas sobre el dolor de las víctimas y la promoción de correlatos donde se posiciona a un perpetrador $i$ en realidad que se requiere promover? ¿se requiere de una ética del turismo y una ética de la memoria para plantear un turismo responsable? ¿Quienes tendrían que hacer parte de estas apuestas turísticas? ¿Hasta qué punto las experiencias culturales pueden ser susceptibles de convertirse en experiencias turísticas? ¿es válido pensar en una relación entre el turismo y los procesos de reconciliación? En este proceso ¿qué pasa con las ciencias sociales y humanas, acaso no les corresponde abordar un objeto de estudio como el viaje?

Vale la pena advertir, que lo que se enuncia en este capítulo no constituye una propuesta de emprendimiento turístico enmarcada en una especie de marketing de la memoria, ni mucho menos en la elaboración de un producto o un modelo turístico en capacidad de homogeneizarse. De entrada, se abandona la idea clásica del turismo que reduce el viaje a "un espacio banal de esparcimiento" afianzada en la lógica de ocio y tiempo libre propio de una cultura de viaje entronizada en la actividad económica, que promueve la idea de un viajero que goza de una relativa falta de condicionantes Esta ideología del viaje refirmada en la literatura de viajes con las historias de viajeros burgueses victorianos y contaminada por la localización de clase, género y raza, constantemente refuerza la idea del

\footnotetext{
${ }^{8}$ Corroborar en https://pabloescobartour.co
} 
cosmopolitismo, el elitismo y la escasa movilidad de personas con pocos recursos (Clifford, 1995).

Más que plantear una nueva teoría sobre un objeto de estudio como el viaje, la pretensión de este capítulo apunta a plantear la necesidad de retomar las reflexiones y las propuestas sobre la necesidad de comprender los conocimientos del viaje y el fenómeno de desplazamientos de diferentes itinerarios culturales, más cuando se hacen evidentes en temas tan sensibles como los conflictos, la memoria y la reparación simbólica. De esta manera, una forma para pensar y proponer nuevos sentidos en el abordaje del viaje como objeto de estudio es precisamente en el planteamiento de nuevas relaciones entre turismo, la memoria y la reparación simbólica.

Finalmente, abordar la relación propuesta entre turismo, memoria y los procesos de reparación simbólica implica plantear un recorrido epistemológico y conceptual en cuatro direcciones. En primer lugar, se hace necesario realizar un acercamiento al estatuto epistemológico del turismo como disciplina para comprender su estructuración y su diversificación. En segundo lugar, desde las múltiples tipificaciones del turismo, se propone identificar las relaciones entre el turismo, el patrimonio cultural y la aparición de propuestas emergentes conectadas con las relaciones entre (turismo y memoria) y (turismo y conflicto). En tercer lugar, desde estas problemáticas que vinculan temas relacionados con las ciencias sociales, se proponen puentes entre los diferentes repertorios materiales e inmateriales objetivados y legitimados como patrimonio cultural y otras formas culturales menos reconocidas dentro de las dimensiones del patrimonio cultural como legados o conjunto de bienes culturales dignos de conservación. Por último desde experiencias asociadas al conflicto armado colombiano, se busca resignificar las comprensiones sobre las relaciones entre viajero y el turista al acoger unas propuestas teóricas de la sociología y la antropología, que permiten una comprensión más allá de las versiones predominantes del turismo.

\section{Acercamiento al estatuto epistemológico del turismo}


Desde la segunda mitad del siglo XX se hace evidente el repunte de la industria turística con un aumento considerable en la generación de riqueza y el aumento de su representación en el PIB, inicialmente en los países europeos y en los Estados Unidos y posteriormente en todo el planeta. De acuerdo con Jafari (2005) en 1950, 25,3 millones de turistas generaron US\$2.100 millones. A finales del siglo XX, en 1998, el número de turistas internacionales estaba ya en 625 millones que gastaron US\$445 millardos. Ese mismo año, el gasto mundial total por turismo internacional y doméstico superó los tres mil billones de dólares americanos (p40) De acuerdo a las cifras de la OMT para el 2017 se registraron un total de 1.326 millones de llegadas de turistas internacionales en destinos de todo el mundo, en torno a 86 millones más que en 2016. Los ingresos por turismo internacional aumentaron en un 4,9\% en términos reales (cifra ajustada por la fluctuación del tipo de cambio y la inflación), hasta alcanzar los 1,34 billones (1.340.000 millones) de dólares de los EE.UU. en 20179 . Estos datos económicos no hacen más que confirmar la importancia del turismo como actividad económica y como alternativa de desarrollo.

Estos impactos en la economía mundial permitirían pensar en la posibilidad de un estudio más detallado sobre la actividad turística y sus impactos como fenómeno social. Sin embargo, esta inclinación del fenómeno turístico hacia su comprensión como actividad económica ha permitido que los temas sociales y las conflictivas relaciones culturales de los viajeros con los espacios y los territorios visitados, no sean uno de los centros de interés del estudio del turismo como objeto de estudio (Llano, 2017). Asociada más a la súper industrialización, el turismo es pensado como experiencia pre programada en forma de servicio que difícilmente relaciona la pregunta por la alteridad (Donaire, 1993, 179 citado por Yori, 2006 p 118).

Aunque son evidentes los resultados del turismo como actividad económica, son escasos los desarrollos teóricos y metodológicos en relación con la consolidación de un corpus de conocimientos específicos sobre el turismo. El interés de diferentes agencias y agentes por darle una mayor autonomía relativa al turismo, lo han ubicado dentro de unas visiones más funcionalistas y sustentables que abarcan las denominadas ciencias administrativas y de la gestión que han vinculado al turismo dentro de un campo de operaciones rentable, pero valga

Cifras consultadas el 22 de marzo en: Panorama OMT del turismo internacional Edición 2018 
decir poco estudiado. Aunque algunos autores como Campodónico y Chalar (2011) han intentado darle al turismo un status como campo de conocimiento transversal desde el pensamiento complejo, lo recurrente es la vigencia de la comprensión turística dentro de la doctrina general del turismo propuesta por Huziker y Krapf desde 1942.

Estas visiones funcionalistas relacionadas con el ocio y el tiempo libre, han dado protagonismo a variables como el dinero gastado, los motivos de viaje y el tiempo recorrido. Desde estas perspectivas asociadas a comprender el turismo como actividad económica, se reivindica el control de tiempo y el espacio en relación con las motivaciones del viaje bajo una serie de actividades programadas que han sido denominadas y criticadas por algunos autores como la excesiva planificación del viaje (Augé, 2008). Estas críticas de Auge sobre la transformación de las antiguas vacaciones caracterizadas por veraneantes, el recorrido de paisajes y el encuentro con otros seres humanos, se dirigen específicamente a la ficcionalización del mundo y a la empaquetadura de viajes que han hecho de la naturaleza y de la cultura un producto susceptible de ser consumido. Al respecto el antropólogo francés sostiene lo siguiente:

Pero, entendámonos bien: viajar, sí, hay que viajar, habría que viajar, pero sobre todo no hacer turismo. Esas agencias que cuadriculan la tierra, que la dividen en recorridos, estadías, en clubes cuidadosamente preservados de toda proximidad social abusiva, que han hecho de la naturaleza un "producto", así como otros quisieran hacer un producto de la literatura y del arte, son las primeras responsables de la ficcionalización del mundo, de su desrealización aparente; en realidad, son las responsables de convertir a unos en espectadores y a otros en espectáculo. El mundo existe todavía en su diversidad. Pero esa diversidad poco tiene que ver con el calidoscopio ilusorio del turismo (p16)

Estas denuncias que ya se habían instalado entre los años setenta y noventa promovieron críticas a un turismo de masas donde se arguye que la industria turística se relaciona con los dividendos económicos de grandes empresas en detrimento del bienestar de las personas y de la cultura. Además, estas críticas coinciden con las denuncias que en 1967 hiciera Guy Debord sobre la sociedad del espectáculo donde se argumentó que la cultura se había transformado en mercancía. De ahí que, la actividad turística fuera entendida como 
simulación y simulacro de la sociedad contemporánea bajo el modelo de Disneylandia (Baudrillar, 1977, p25). En este panorama, el turismo como objeto de estudio empezó a ser abordado con mayor rigurosidad desde la sociología, la antropología, pero eso sí, sin abandonar las variables propias de la concepción clásica del turismo bajo las variables del origen de los turistas, los gastos efectuados por ellos y los niveles de ocupación (Campodónico y Chalar, 2011)

De acuerdo con Jafari (2005) desde la denominada plataforma precautoria del turismo, no solo se realizaron una serie de críticas a la visión dominante del turismo (plataforma apologética), sino que estas dieron paso a una tercera plataforma donde prosperaron unas formas de desarrollo alternativo del turismo. Desde la plataforma adaptativa aparecen como estrategias prescritas nuevas formas de diversificación del turismo. Entre ellas se encuentran el agroturismo, turismo apropiado, turismo comuno-céntrico, turismo controlado, turismo de granja, turismo cultural o étnico, ecoturismo, turismo verde, turismo indigenista, turismo vital, turismo de naturaleza, paraturismo, turismo responsable, turismo rural, turismo sensitivo, de baja intensidad, turismo suave o turismo sostenible; la lista sigue creciendo e incluye el «no turismo» como una alternativa más (pp 42, 43).

Ya para los años noventa, el abordaje del turismo desborda el ámbito netamente económico referido únicamente al ocio y al tiempo libre y abre sus posibilidades de aplicación al plano de la cultura con mayor rigor en el denominado turismo cultural. Esta comprensión de la experiencia turística asociada a la búsqueda de sensaciones, experiencias memorables y autenticidad abrió las posibilidades de reafirmación del turismo de aventura, el turismo de fantasía y el turismo cultural. Con la carta de turismo cultural de la Unesco de 1976, el turismo pasó de estar vinculada con el conocimiento de monumentos y sitios históricos y artísticos a vincular toda suerte de repertorios simbólicos como la gastronomía, las músicas y diferentes archivos y tradiciones orales que pudieran expresar testimonios significativos y legados de las comunidades. Esta apertura cada vez mayor de la actividad turística a otros sentidos y significados, ha incorporado las reflexiones sobre la cultura, el patrimonio cultural, en sus diferentes acepciones como patrimonios lingüísticos, literarios, históricos, arqueológicos, religiosos, para ponerlos en valor, desde el intercambio cultural en la forma 
de itinerarios culturales y recorridos turísticos. De acuerdo con Hernández (2015) en el contexto general de la disciplina proliferan nuevos ámbitos de estudio "uniendo a los dominios más clásicos, otros asuntos tan dispares como el género, la salud, la medicina, la denominada antropología de las edades, la alimentación, el deporte, la pesca, el turismo, la antropología industrial y de la empresa, la educación o el patrimonio (p308)

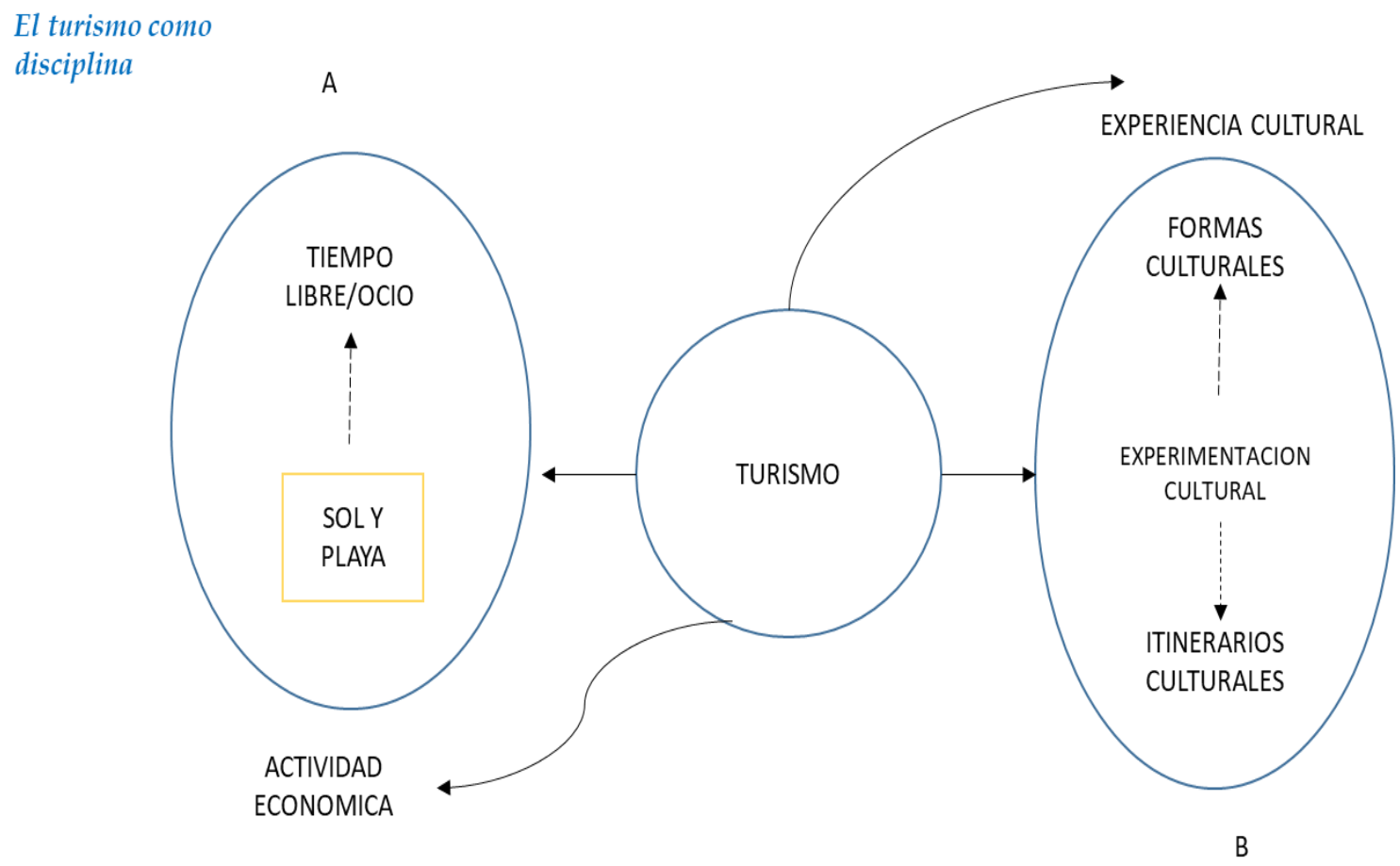

En el caso del turismo cultural y otras variaciones como turismo experiencial y turismo literario, estas reflexiones sobre el producto turístico se han extendido a unas formas mucho más experienciales y culturales asociadas al patrimonio, que valga decir, caen en la reproducción y asimilación de las versiones oficiales de la historia y en las anécdotas propias de este tipo de narración sobre el pasado. Ahora bien, estos procesos de organización disciplinar asociados principalmente a procesos económicos bajo la práctica de la planificación del viaje, busca una apertura mayor para los años noventa donde se hace evidente una participación cada vez más activa de otras disciplinas de las ciencias sociales, que dan lugar a ciertas diferenciaciones como turismo rural, turismo de aventura, ecoturismo, turismo de fantasía, turismo cultural. En esta discusión es importante admitir que la 
hegemonía de disciplinas asociadas a la gestión, la administración y los procesos económicos mantienen incólumes.

En los términos antes mencionados, la actividad turística se enmarcó inicialmente en el ocio y el tiempo libre bajo una concepción funcionalista. Además, desde esta concepción prosperó una comprensión del fenómeno turístico como actividad económica que hasta hoy sigue siendo predominante. Lo que hace fuerte este predominio económico y administrativo sobre el turismo es precisamente la búsqueda nuevos mercados para el turismo como actividad que redunda directamente en la economía de los países, las ciudades y las regiones. En este contexto, el fenómeno turístico como actividad económica ha diversificado su mirada a concepciones mucho más culturales y experienciales, que no solo ha permitido una explosión de la oferta turística bajo múltiples tipificaciones, sino unas nuevas significaciones para la epistemología del turismo enmarcadas en la autenticidad y la memorabilidad de la experiencia turística ${ }^{10}$.

\section{La diversificación del turismo como actividad económica y su relación con el patrimonio cultural}

Esta explosión del turismo antes mencionada se inserta dentro de la ambigüedad que demarca el campo de estudios de la conservación del patrimonio cultural, que valga decir, se debate entre un interés altamente especializado y una difusión de los valores del patrimonio cultural como la autenticidad, la antigüedad, lo artístico y la utilidad comercial. Desde estas consideraciones prospera el uso turístico del patrimonio bajo la aprehensión didáctica y una escenificación mercantilizada de la cultura (González, 2015). Desde estas comprensiones y usos de la cultura, ha prosperado el turismo cultural que ha involucrado en la difusión de los repertorios simbólicos, los denominados lugares de memoria y lugares patrimonio bajo una

10 Cabe mencionar que, para Colombia, esta relación entre patrimonio cultural y turismo cultural quedó supeditada y agenciada por el ministerio de Comercio, Industria y Turismo desde el primer gobierno de Álvaro Uribe Vélez. De acuerdo con Sánchez Voelkl (2014) el debate entre ministerios da cuenta de los avances del discurso dominante del gobierno nacional dentro del sector cultural a través del Grupo de Turismo Cultural. La aparición del grupo de asesores y la confrontación que suscitó la implementación de la política de turismo cultural cuestionan, de facto, el rol institucional de Mincultura frente al patrimonio cultural, ante las comunidades que habitan los destinos patrimoniales y frente a la autonomía y el respeto que debe resguardar la institución en el proceso de construcción y afirmación de las identidades diversas(p142) 
idea anquilosada del patrimonio cultural asociada a las comprensiones de elementos cohesionadores de la cultura y de las identidades nacionales del siglo XVIII y XIX, donde por supuesto se encuentra entronizada las formas de hacer historia más clásica y anquilosada ${ }^{11}$.

Amarrada a idea de la ilustración y la expansión del sentimiento nacionalista, prospera un turismo cultural bajo tras características fundamentales. La primera de ellas un reconocimiento de la transcendencia histórica de los monumentos, la segunda sobre la exaltación del valor estético de los monumentos y tesoros artísticos de la modernidad y la tercera de ellas es la narrativa asociada al valor pedagógico de su conservación. Estas versiones oficialistas de la historia se han difundido desde las empresas turísticas y los guías turísticos, que, formados desde las concepciones clásicas del turismo, replican en los guiones interpretativos bajo anécdotas, datos y personajes esas concepciones historiográficas de la historia de los vencedores.

En este sentido, la relación que se puede establecer entre turismo y memoria se enmarca inicialmente dentro de la diversificación del turismo como actividad económica. Esta explosión de innumerables posibilidades de presentación del producto turístico ha permitido explorar, en la relación turismo y memoria, turismo y conflicto, y turismo y reconciliación, otras posibilidades comerciales y de promoción de lugares y de actividades turísticas en lugares y espacios donde se viven o se ha vivido el recrudecimiento de la violencia y los conflictos armados. Esta búsqueda de representaciones actuales o del pasado, asociadas al conflicto para "nutrir" el consumo de sitios de muerte, de representaciones traumáticas y de espacios del conflicto, han permitido la difusión de un turismo bajo la forma de turismo oscuro, turismo de memoria, tanatoturismo, turismo de reconciliación entre otros.

\footnotetext{
${ }^{11}$ El historicismo del siglo XIX establece unos criterios básicos para pensar el pasado. El primero de ellos establece que lo que sucedió debe explicarse en el momento en que sucedió y el segundo criterio relevante, es que existe una ciencia dotada de específicos procedimientos lógicos, para desentrañar lo que sucedió. Desde una postura Neopositivista de la ciencia, la historia según Roch (2001) pretendió un estatus científico apartándola de la narración y la experiencia biográfica. La escuela de los anales quiso fundar una ciencia histórica centrada en las estructuras, dejando de lado la narración. De esta manera, los hechos históricos eran regularidades bajo el modelo nomológico - deductivo. La crítica de Anales frente a esta corriente. (Escuela metódica) radicaba en que una historia lineal de acontecimientos tendría la tendencia a convertirse en narración.
} 


\section{3. las relaciones entre turismo y memoria: un acercamiento a la experiencia cultural del viaje}

Algunas propuestas que llaman la atención son las que se vinculan a la relación entre el conflicto y el turismo. Bajo la industrialización del testimonio, la popularidad del perpetrador y un marcado aumento en lo que algunos autores denominan la construcción de memorias en ajuste a la demanda, aparecen estas dinámicas del turismo asociado a la participación creciente de población local vinculada a problemáticas conflictivas que se aferran a políticas de la memoria arbitradas principalmente por el Estado, por lo menos en tres tendencias. En primer lugar, está la tendencia que busca gestionar y lidiar el pasado a través de procedimientos de justicia retroactiva, instauración de conmemoraciones de fechas y lugares, apropiaciones simbólicas, grandes ofertas de sentido temporal o narrativas más generales. En segundo lugar, acciones institucionales concretas que se traducen en el diseño y desarrollo de planes, programas y proyectos. En tercer lugar la tendencia que hace evidente en la promoción de políticas de memoria, las relaciones de fuerza y sentido en torno a la simbolización del pasado, el ordenamiento del presente y la orientación del futuro (Palacios, 2010).

Bajo estas políticas aparecen formas emergentes del turismo, que buscan la vinculación de expresiones locales y culturales para lograr con esto mayor difusión dentro del denominado marketing turístico ${ }^{12}$. De acuerdo con Pérez et al (s.f) ciudades como Medellín representan un claro ejemplo de la promoción de la ciudad marca y de focos de aplicación de estas propuestas que se vinculan con la inserción y la promoción de temas como el sicariato. Además de involucrar temas de reconciliación entre pandillas de algunas comunas en la

\footnotetext{
12 De acuerdo con Folgado Fernández, J., \& Oliveira Duarte, P., \& Hernández Mogollón, J. (2011) en una industria turística rodeada de cambios constantes, un desafío clave para las empresas es poner en valor su marca; la gran mayoría de los turistas escoge sus destinos por la marca e imagen que percibe de ellos. Así muchos lugares buscan implantar técnicas de promoción a través de la creación de imagen de marca, en un esfuerzo por diferenciar sus identidades y subrayar el carácter único de su destino (...) El sector turístico busca adelantarse a la demanda futura conociendo cada tipología de consumidor, acotando el tiempo que dedicará, su distribución anual y la elección del destino. La percepción obtenida entre las expectativas de los turistas, y lo realmente obtenido una vez terminado el viaje es vital para la consolidación de una marca de destino, su imagen y la fidelización de los consumidores ante futuras visitas (Pp 905-907)
} 
ciudad de Medellín, la promoción de la violencia de la ciudad se convierte en un elemento de atracción de los turistas. Para hacer más atractivas estas propuestas turísticas que hacen parte de la turistificación de Medellín se ha pretendido involucrar a líderes sociales, madres de hijos desaparecidos, para resaltar "el lado oscuro" de la ciudad que ha sido representada en las series de capos transmitidas por plataformas tan poderosas como Netflix.

Cabe anotar que no todas las propuestas giran alrededor de la figura del sicario y el capo. A estas rutas se superponen algunos circuitos turísticos relacionados con el grafiti, la música y el teatro, presentes en los barrios Moravia y la Independencia. También buscan destacar algunos elementos de desarrollo urbano de la ciudad como por ejemplo las escaleras eléctricas de la comuna 13 en Medellín, el jardín de Moravia que recibió el premio Lee Kuan Yew World City Prize a la innovación urbana y ambiental, la biblioteca España, levantada tras la visita de los reyes de España a Medellín y posteriormente cerrada por deterioro en su fachada. En estos recorridos, no puede faltar la visita al museo casa de la memoria que busca desde su misión aportar a la construcción de memorias. Uno de los principales problemas que se presentan a la hora de vincular diferentes repertorios simbólicos y culturales a este tipo concreto de actividad turística, es el carácter difuso de los límites de lo representado, es decir, las propuestas giran alrededor del discurso oficial, la exageración de algunos pobladores que simpatizan con el turista y las mismas resistencias de líderes sociales para aceptar la legitimidad de los recorridos y la forma en que diferentes empresas turísticas se han emplazado en los territorios locales (Pérez et al s.f)

Un caso contrario al de estas resistencias locales lo representa la iniciativa de Afavit (Asociación de Familiares de las Victimas de Trujillo) quienes lograron tipificar y realizar un itinerario alrededor de la masacre de Trujillo. Esta experiencia resulta significativa en tanto, hace parte de una construcción elaborada desde archivos orales y experienciales para la reparación simbólica. A continuación, se mencionan los principales puntos propuestos por esta asociación ${ }^{13}$

\footnotetext{
${ }^{13}$ El presente texto se inscribe en el marco del itinerario a Trujillo Valle, realizado en el año 2018. Este itinerario hizo parte de una de las salidas de campo previstas para la presentación de los respectivos informes de investigación de la presente investigación. En forma de diario de campo, el siguiente apartado recrea el itinerario alrededor del Parque-monumento donde se intenta resaltar las versiones de los participantes en la
} 


\section{PUNTOS PROPUESTOS}

\section{DESCRIPCIÓN DEL RECORRIDO}

\section{Parque- \\ Monumento. \\ Trujillo Valle}

\section{El parque}

La llegada a

\section{parque}

Al llegar a Trujillo, su plaza principal es similar a muchas plazas principales de diferentes pueblos de Colombia. El parque monumento que conmemora a las víctimas entre 1987 y 1994 en los municipios de Trujillo, Riofrio y Bolivar del Valle del Cauca, 300 casos de violaciones a los derechos humanos. Uno de los inicios de la historia del Parque-monumento de Trujillo, está relacionada con procesos de impunidad que se establecieron por parte de autoridades locales respecto a los casos de asesinato y desaparición de las aproximadamente trescientas personas de los tres municipios mencionados, situación que se conoce de manera general como "La masacre de Trujillo", lo cual derivó en que el caso se llevara a instancias internacionales, específicamente a la Comisión Interamericana de Derechos Humanos de la Organización de Estados Americanos OEA, lo cual creo a su vez una comisión conformada por autoridades nacionales, defensores de derechos humanos y familiares de las victimas (Comisión de investigación de los Sucesos Violentos de Trujillo) la cual elaboró un informe en 1995 con recomendaciones al Estado colombiano, el cual implicó la aceptación de responsabilidad por parte del presidente de ese momento, en el mismo año de publicación del informe y la aceptación de las recomendaciones de la OEA, una de ellas, la construcción del Parque monumento, como parte de la reparación a las víctimas.

El parque tiene un perímetro de seis hectáreas, el cual fue adquirido por la Red de Solidaridad Social entre 1996 y 1997, este último, siendo el año en el que se contrataron los diseños del Parque el cual inicio su construcción en 1998. Es importante decir que la Comisión Intercongregacional de Justicia y Paz jugo un papel muy importante en el proceso de enlazar los diseños arquitectónicos a los sentires de las víctimas, con el acompañamiento de profesionales de la educación, así como relacionados con la psicología y psiquiatría, a través de talleres con los familiares que sufrieron pérdidas en este proceso de victimización de sus seres queridos. Aunque existe una diferencia respecto a los diseños iniciales y la construcción final, debido a diversas circunstancias, esta última se ha llenado de sentido y significado de la misma manera en cómo se concibió en los diseños iniciales. Lo que en los diseños iniciales era conocido como el "Camino de las esculturas" conmemorando los principales crimenes de lesa humanidad en Colombia y en el mundo en el siglo XX, inicia el recorrido con unas estaciones en donde existen fotografías y una descripción general de uno de los hechos acontecidos en el país. Alli se encuentra la masacre del Salado, Guaitarillas, San José de Apartadó, entre otras, en una pequeña estructura de madera, bajo un techo en tejas de barro, las cuales se encuentran a lado y lado de un camino ondulante y en ascenso.

l Para llegar al Parque-Monumento desde la plaza central, es necesario caminar apenas tres cuadras y encontrar allí la sede de Afavit (Asociación de Familiares de las Victimas de Trujillo) en donde existen en su exterior, algunos mensajes, pinturas e imágenes relacionadas con el acontecimiento. El recorrido puede iniciar por allí mismo, o también se puede dejar para el final de la ruta, en donde se encuentra una oferta complementaria de la asociación relacionada con productos de diferente tipo que ofrecen a los visitantes los pobladores y familiares. A pesar de llevar varios años, el parque monumento no es muy visitado por los pobladores del pueblo. Es poco conocido, hasta el punto de no tener muy claro porque se levanta alli este

Asociación de Familiares de Víctimas de Trujillo, AFAVIT y la hermana Maritze, quien sin duda es una de las responsables del nivel de consolidación del proceso de Trujillo. 
dispositivo que busca recordar a las personas que en diferentes circunstancias desaparecieron o perdieron la vida en el marco de un conflicto interno.

Propósito

El recorrido por estas estaciones es claro: brindar el contexto en el cual ocurrieron los hechos de Trujillo y entender por supuesto que no se trató de ninguna manera de un hecho aislado, sino por el contrario, que fue una tendencia a nivel nacional, donde por supuesto los actores, los nombres de los responsables y los lugares fueran diferentes, es decir, la misma película, pero con diferentes actores y escenarios.

Placas Inicialmente pensado como osarios -en donde los familiares de las victimas realizaron una intervención sobre las placas que conmemoran la muerte o desaparición de un familiar, así como el deceso por "pena moral" de un allegado a raíz de la perdida- se continua la ruta en ascenso hacia unas terrazas que siguen el camino serpenteante del cerro, en donde en plazas incrustadas a modo de osarios, se encuentran el nombre de las víctimas. En este punto, la altura del cerro, permite que esta parte del recorrido sea un mirador que invita a la contemplación del horizonte, en donde invita al recogimiento y la posibilidad de pensar en lo que pasó en estos municipios del Valle del Cauca y en el país.

Mausoleo Luego de recorrer este segmento de la ruta, a modo de mirador, se encuentra el Mausoleo del padre Tiberio Fernández, el cual fue asesinado y descuartizado, por lo que se conmemora su imagen, su oficio y los motivos por las cuales fue asesinado. Es un espacio pequeño que guarda fotografías, un crucifico y una mesa en piedra, en donde también se encuentran fotografías de otras personas desaparecidas y algunos dibujos y pinturas de los niños de la región.

Mural Al finalizar el ascenso se encuentra un mural que fue modificado ya que, valga decir, en no pocas ocasiones ha sido atacado y destruido parcialmente, de hecho, en el momento que se realiza la visita en el marco de la Peregrinación por la memoria 2018 la cual se realiza cada año, es visible que del mural se borró una reciente amenaza escrita con spray de lado a lado del mural. Allí se realiza una pequeña ceremonia católica, se saluda a las personas, se canta, en definitiva, se comparte y se recuerda a quienes ya no están.

Casa de la La casa de la Asociación es sin duda una casa de la memoria, el cual se configura memoria de AFAVIT: Fotografías, pancartas, periódicos... como un archivo abierto al público en el cual se encuentran fotografías de quienes enfrentaron esta ola de terror, objetos relacionados con su ocupación, información en periódicos nacionales y regionales, revistas, mapas, historias, las cuales dispuestas en cada una de las paredes y el segundo piso de la casa, cuentan la historia de una tragedia humanitaria que ocurrió y que busca que en efecto la memoria se constituya como una garantía de no repetición de hechos victimizantes.

\title{
La novia del rio
}

De la misma manera, en el desarrollo de la ruta, aparecen en ella distintos relatos que se configuran como archivos orales vivos de quienes como en el caso de la "Novia del río", una pobladora de Trujillo, se ocupaba de sacar en las tardes, los cuerpos que bajaban por el río para darles una sepultura apropiada. Esta historia, junto con los relatos que se entretejen alrededor de la memoria de las víctimas, permite mantener la memoria de lo que sucedió.

Fuente. Autores Una ruta por la memoria: Itinerario cultural de Trujillo Valle

\begin{abstract}
Ahora bien, el Centro Nacional de Memoria Histórica dentro de las metodologías de investigación que ha desarrollado ha definido casos emblemáticos, así como ejes temáticos al caracterizar los diferentes hechos victimizantes que se han producido en el marco del conflicto armado en Colombia. En este sentido el caso de Trujillo, Valle del Cauca, está
\end{abstract}


tipificado como un caso emblemático. Lo que habría que mencionar es que el CNMH establece 5 ejes temáticos de investigación distribuidos en Causalidades, discursos y representaciones, Mecanismos, población civil e impactos. Desde estos ejes se busca avanzar más allá de reflexiones teóricas y metodológicas en la inclusión de distintos tipos discursos, actores, versiones, intenciones, que se complementan y contradicen configurando de esta manera un campo de conocimiento que difunde información, establece problemas, construye conceptos, categorías y teorías, para realizar una contribución a las Comisiones de la verdad, la reparación de las víctimas, y el establecimiento de dispositivos pedagógicos como en algunos casos, la Cátedra de Paz y Convivencia ${ }^{14}$.

Estas memorias gubernativas reafirmadas sobre todo por la posición de historiadores incluyendo las versiones más disidentes, por lo general, tienden a pasar por alto según Acevedo (2012) los modos y prácticas en que las victimas conciben sus propias memorias y que son excluidas como memorias subalternas y memorias reservadas. Lo que queda claro para todas aquellas iniciativas que intentan relacionar el turismo con las memorias, es precisamente el carácter problemático que tiene su definición. Más que comprender la construcción social e histórica de las diferentes memorias en el plano de recuerdos aislados y de conceptualizaciones sin mayores validaciones de las víctimas, lo que habría que tener en cuenta a la hora de plantear escenarios turísticos, es la naturaleza conflictiva de la memoria. Como conquista y como lucha constante por imponer unas versiones legitimas sobre el recuerdo y el olvido no se puede pasar por alta que la comprensión de la memoria en Colombia es más bien un objeto de luchas, donde por supuesto existen procesos de legitimación cultural y exclusión.

La dificultad de esta relación entre turismo y memoria radica precisamente en la escasa comprensión del turismo como disciplina y la memoria como categoría histórica. Para lograr

${ }^{14}$ De la misma manera el CNMH distingue tres tipos de memoria: memoria social, memoria colectiva y memoria mediada. De manera resumida se puede decir que la primera hace referencia a cómo los familiares de las víctimas y en general los testigos ligados a los hechos victimizantes recuerdan, atribuyen sentidos y significados a lo que ocurrió. La segunda distinción hace referencia a la memoria que se produce en la dinámica entre la primera y la tercera, configurando de esta manera la memoria colectiva. Finalmente, la memoria mediada, hace referencia a quienes median/agencian la memoria, ligados a organizaciones como la iglesia católica, la Comisión, en el caso de Trujillo, la Asociación de Familiares de Víctimas de Trujillo, AFAVIT y de la misma manera, las versiones ligadas a los perpetradores 
construir puentes entre el turismo más alla de sus comprensiones técnicas y operativas y el estatuto de la memoria habria que considerar de entrada algunas impliciones de una categoria tan sensible como la de memoria o memorias. Tal como advierten Serna (2012) es importante tener en cuenta que reducir la memoria como sepultura de los abatidos de la historia supone de entrada, desconocer el estatuto de la memoria. La comprensión de la memoria ha de pasar por su reconocimiento como categoría histórica ligada directamente al pensamiento social ${ }^{15}$.

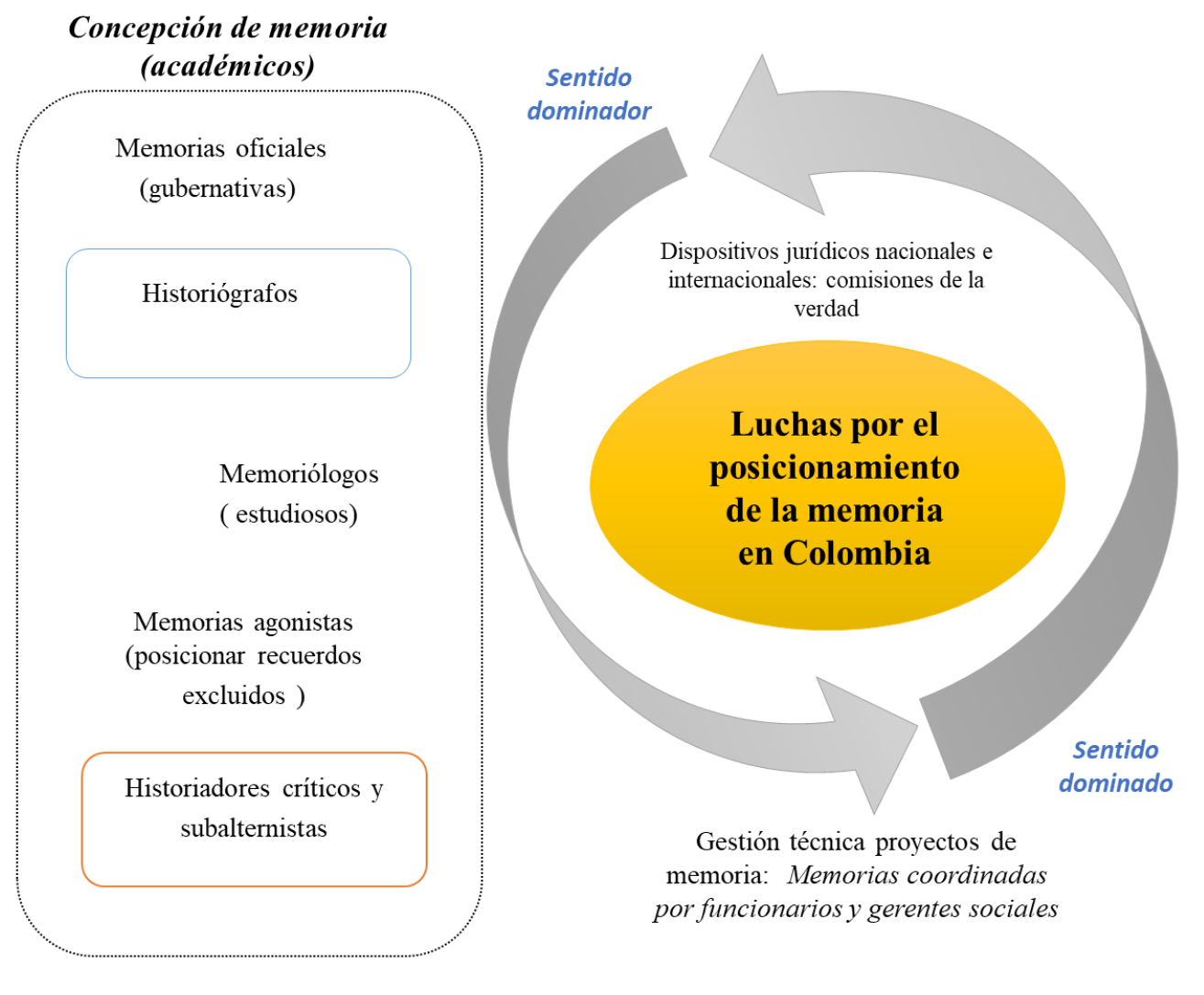

Modos y prácticas en que las victimas conciben dichas memorias

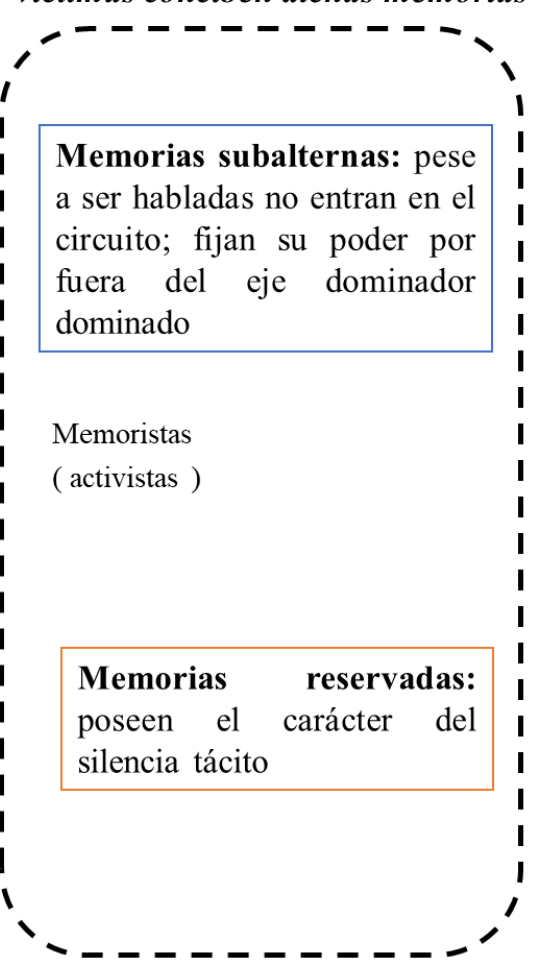

${ }^{15}$ Esto de entrada permite comprender cómo esta categoría está presente en las texturas de la existencia, en los entramados sociales y en los tejidos institucionales. Estas composiciones materiales y simbólicas permiten además comprender por qué el tema de la memoria ha estado vinculado con los conflictos, las violencias como parte del estatuto crítico del mundo social. La producción de la memoria implica una lucha constante por la creencia y contra la creencia. Esto implica la existencia social e histórica de sistemas de relaciones simbólicas que buscan imponer visiones del mundo social y formas legítimas y legitimadas de las representaciones el pasado. Es además la posibilidad de la fetichización de la memoria, oscureciendo las relaciones de su producción histórica por medio de dos mecanismos que hacen de la memoria una presencia siempre ausente. De un lado aparece la reducción de la memoria a trauma que no hace más que revictimizar como una ausencia sostenida. De otro lado aparece su reducción a mero complejo de culpa que la muestra como una presencia nunca adquirida (Serna,2012). 
Ahora bien, las relaciones que se pueden plantear desde la actividad turística y estas advertencias sobre la comprensión de la memoria como parte consustancial del pensamiento social implica una serie de consideraciones a saber. En primer lugar, que el asunto de la memoria requiere desligarse de un carácter homogéneo que la reduce a unas versiones del pasado oficiales. En segundo lugar, aceptar los múltiples sentidos, posiciones y disposiciones que existen alrededor de la memoria, permite constatar a la memoria como un objeto en disputa inscrito en relaciones de fuerza históricas y en los mismos conflictos y producciones culturales ${ }^{16}$. En este sentido, la producción de la memoria ha de constatarse en sus diferentes luchas por la imposición de representaciones del pasado y de la imposición de unas visiones y divisiones del mundo social (Serna, 2001; Chavarro y Llano, 2010). En tercer lugar, es importante reconocer que estos arbitrajes sobre la memoria generalmente están precedidos por el Estado que decide, promueve, avala, y ejecuta políticas de memoria (Canclini, 1994; Palacios 2010) De acuerdo con Bourdieu, (2014) se podría decir que el Estado es el lugar de circulación de la palabra oficial, del reglamento de la regla, del orden, del mandato, de la denominación. Es aquí donde están en juego las diferentes representaciones sobre lo identitario, las luchas sociales y culturales por la imposición de un sentido legítimo de la memoria y las confrontaciones por nombrar lo que es digno y legitimo de recordarse.

En cuarto lugar, la posibilidad de promover espacios de memoria como objetos turísticos, pasa necesariamente por la reactivación de la experiencia turística como posibilidad para la reflexión y la implosión de significados alrededor de acontecimientos de necesaria trascendencia para la definición del futuro del país (Araque y Llano, 2018). Ahora bien,

\footnotetext{
${ }^{16}$ Habría que considerar que toda elaboración social y cultural requiere comprenderse desde ambas caras de la moneda: la cultura y la barbarie. Empresas artísticas e intelectuales, el desarrollo de las ciencias naturales, muchas ramas de la erudición florecieron en estrecha proximidad espacial y temporal con las matanzas y los campos de muerte. Me parece irresponsable toda teoría de cultura, todo análisis de nuestras actuales circunstancias que no tenga como eje la consideración de los modos de terror que acarrearon la muerte por obra de la guerra, del hambre y de matanzas deliberadas de unos setenta millones de seres humanos muertos en Europa y Rusia entre el comienzo de la primera guerra mundial y el fin de la segunda (Steiner, 2006, p49).
} 
además de estas consideraciones tan necesarias, habría que inmiscuir una dimensión ética del recuerdo que permita sopesar los ejercicios de memoria mediante una corresponsabilidad de lo que se recuerda y lo que se olvida (Avishai,2001).Finalmente, la importancia de la versión de las víctimas, la multiplicidad de versiones, la selección de fuentes de información desde donde se construye la mediación de la memoria requieren ser tenidas en cuenta en la construcción de guiones interpretativos realizados bajo profundas investigaciones (Araque y Llano, 2018)

Finalmente, como ya se ha mencionado, en esta dinámica ha prosperado la visión de promoción por parte del Estado de los denominados lugares de memoria como atractivos turísticos. Estos núcleos representaciónales que condensan diferentes perspectivas y sentidos del pasado son susceptibles de ser consumidos bajo la lógica de unos discursos más bien apegados a los nacionalismos del siglo XVIII Y XIX ${ }^{17}$. Sin mayores posibilidades de reincorporar repertorios simbólicos que pueden constituir testimonios significativos, rasgos culturales y diferentes valoraciones sociales, la construcción de guiones y rutas turísticas, se alejan de representar verdaderos itinerarios culturales En este sentido, lo que queda en evidencia es la falta de reflexión profunda sobre la experiencia histórica y su relación con las diferentes versiones del pasado. En efecto, la selección de fuentes de información desde donde se construye la mediación turística requiere involucrar diferentes archivos orales en la construcción de guiones interpretativos.

\section{Nuevas rutas, nuevos mundos:}

\section{La reexploración del viaje como objeto de estudio de las Ciencias Sociales}

\footnotetext{
17 Con esto también se reproducen las matrices socioculturales reafirmadas sobre el civilizacionismo que se puede ejemplificar en lo que Steiner (2006) llama el mito del siglo XIX o el imaginario de la cultura liberal caracterizado para Europa por un alto grado creciente de alfabetización; el imperio de la ley, formas representativas de gobierno, resguardo de la vida privada en el hogar y una seguridad cada vez mayor en las calles, el reconocimiento espontaneo del singular papel económico y civilizador que tienen las artes, la ciencia y la técnica (p20) En Colombia estas ficciones que se esconden y se desdibujan entre retóricas y juegos del lenguaje, reclaman la presencia del abogado y del otrora letrado, que valga decir son la representación de la matriz cultural abigarrada en el civilizacionismo del siglo XVIII y XIX y que ha marcado y sigue vigente en esos lenguajes supervivientes de un racismo criollo que se manifiesta en la apariencia (Serna 2006). Estos manejos del lenguaje y esta referencia a la descalificación y a la tipificación también se han desplazado a un currículo prescripto, desde la oficialización de la enseñanza de la historia y la invisibilización del negro en las representaciones del pasado(Ibagón, 2016)
} 
De acuerdo con lo expuesto, la complejidad del turismo en cuanto a la formación de cuerpos de conocimiento involucra varias dimensiones a saber. Una primera dimensión de comprensión, recoge los desarrollos científicos de la naturaleza epistemológica e interdisciplinar del turismo, donde se encuentran principalmente los aportes de disciplinas como la economía, la sociología, la antropología, la historia, la geografía y el urbanismo. Aunque esta participación de estas disciplinas en la construcción de una epistemología del turismo ha estado presente desde la segunda década del siglo XX, no resulta tan clara sus contribuciones puntuales en la discusión del turismo como una disciplina posible (Jafari, 2005). Una segunda dimensión involucra aspectos relacionados con el desarrollo de la industria turística como base de la economía, aspecto suficientemente explicitado en la primera parte de este texto. Sin embargo, habría que advertir que esta dimensión involucra el campo de operaciones del turismo donde se consolida el producto turístico y se estructura la oferta a través de la comercialización y la promoción del producto turístico. Esta dimensión operativa resulta un factor estratégico desde las denominadas agencias de viajes, los promotores y los operadores turísticos, quienes en realidad jalonan la industria turística.

En tercer lugar, aparece un ámbito formativo que responde a esas necesidades del sector turístico y que obedece a procesos formativos del turismo como disciplina universitaria. Aquí se congregan aspectos relacionas con la gestión curricular, las actividades académicas, los planes de estudio y la elaboración de contenidos que respondan al desarrollo de habilidades para desempeñarse en el sector. De esta manera, en esta tercera dimensión es donde más se insiste en mostrar desarrollo, no del talante epistemológico como objeto de estudio y de conocimiento científico, sino como objeto de enseñanza y objeto a enseñar. Este tránsito de las estructuras científicas a las estructuras universitarias, tecnológicas y técnicas, es más bien difuso, en cuanto a que la necesidad de actualización no proviene del desarrollo científico de una disciplina con autonomía relativa, sino del mismo sector turístico como campo de operaciones, lo que lo convierte al turismo en un saber técnico, administrativo y de gestión 
posicionado sobre habilidades blandas, sin mayores discusiones en plano de las ciencias sociales y humanas.

Otro aspecto que refuerza lo anterior, se encuentra en la misma función que cumple la Organización Mundial del Turismo como agencia reguladora y legitimadora de la actividad turística. Esta agencia no solo promueve políticas turísticas en los diferentes países del mundo, sino que, además, articula y organiza a los diferentes países miembros mediante redes y promoción de destinos emergentes. Aunque la OMT promueve la producción, circulación

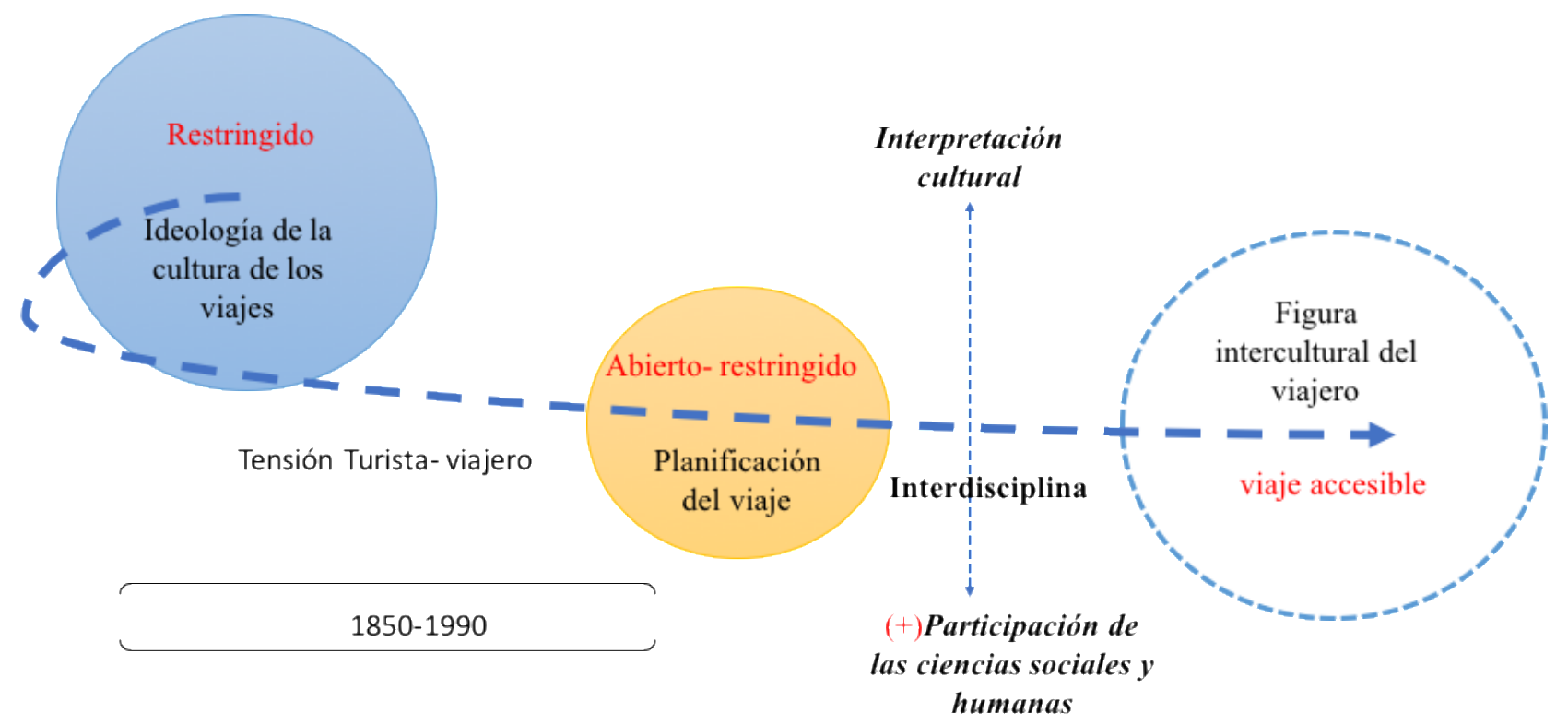

y consumo de literatura referida a la actividad turística, son más bien escasas las investigaciones sobre el fenómeno turístico y el viaje como objeto de estudio. Es por esto que se hace necesario crear y consolidar puentes alrededor de la problemática del turismo para comprender más allá de las visiones económicas y materiales del viaje, los sentidos y sin sentidos del turismo como un objeto de estudio de las ciencias sociales y humanas. Más allá de desconocer los avances del turismo con otras disciplinas donde ha prosperado subdisciplinas como la antropología del turismo, la sociología del turismo, la geografía del turismo entre otras, es importante reclamar para las ciencias sociales y humanas en su conjunto, un esfuerzo decidido para el abordaje de problemáticas relacionadas con el fenómeno del viaje. 


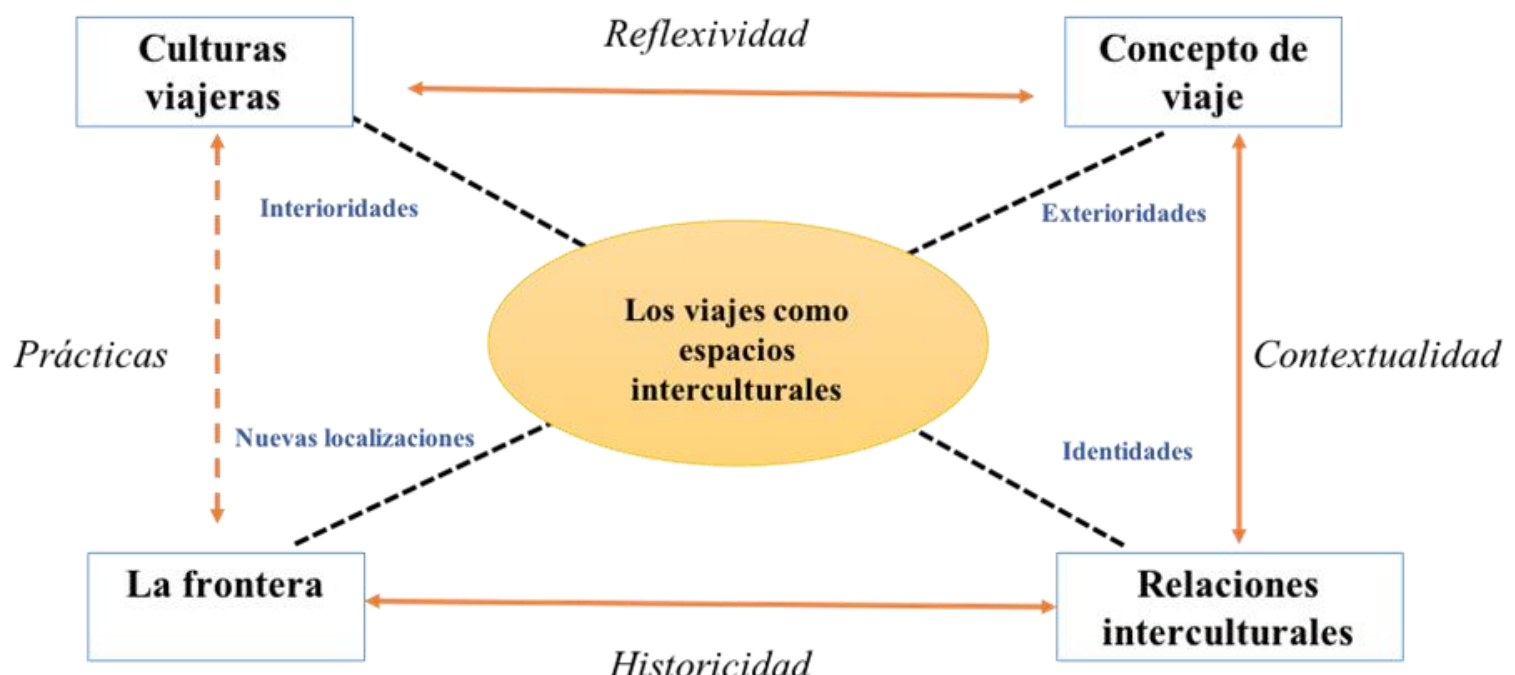

Aunque dicha convocatoria puede resultar un tanto ingenua, la pregunta por la comprensión del viaje resulta llamativa en tanto se desmarque del sentido banal del viaje negativamente considerado y la tensión siempre frecuente entre el viajero y el turista. La cultura como viaje permite involucrar aspectos relacionados con las prácticas espaciales, la simultaneidad del viaje, los desvíos, los retornos de las experiencias de los viajes y la identificación de espacios atravesados por múltiples incidencias culturales (Clifford, 1995). Al tener presente que el abordaje de un fenómeno tan complejo como el viaje puede comprenderse sobre la consideración plural de culturas del viaje y de las experiencias del viaje, se hace posible considerar múltiples relaciones interculturales que se pueden presentar entre el viajero, el recorrido y la experiencia del lugar. Aunque es evidente la contribución de las epistemologías de las ciencias sociales en la definición del turismo como disciplina, se hace necesario llamar la atención en una mayor participación de las ciencias sociales para comprender hoy el fenómeno social y cultural del viaje y el recorrido. Obviamente esta reflexión excede por mucho el alcance de este pequeño texto. Sin embargo, se proponen algunas reflexiones, que más que cuestiones concluyentes, lo que buscan es animar la discusión y el debate.

Los puentes que se pueden construir entre los viajes como espacios sociales, culturales y simbólicos y las relaciones de proximidad, cercanía e incluso desorientación permiten conectar por medio de la interdisciplinar a las ciencias sociales, para comprender el significado de las culturas viajeras. Se insiste en la comparación cultural y en la inclusión de variedad de prácticas culturales entendiendo el viaje como un término de comparación 
cultural precisamente en razón de su contaminación histórica, de sus asociaciones con organizaciones pertenecientes a un género, a una raza y a privilegios de clase, medios de transporte específicos, rutas transitadas, agentes fronterizos entre otros, es por esto que se requiere mayor amplitud conceptual para incluir en el concepto de viaje variedad de prácticas culturales, materiales y espaciales que producen saberes, historias , tradiciones compartidas, músicas, libros, diarios y otras empresas culturales (Clifford, 1995 pp16-20). Aquí aparece la posibilidad de involucrar no solo archivos escritos sino orales y también la necesidad de contrastar las fuentes orales y escritas mediante reflexiones y debates sobre las fuentes y la implicación de adoptar diferentes metodologías ${ }^{18}$.

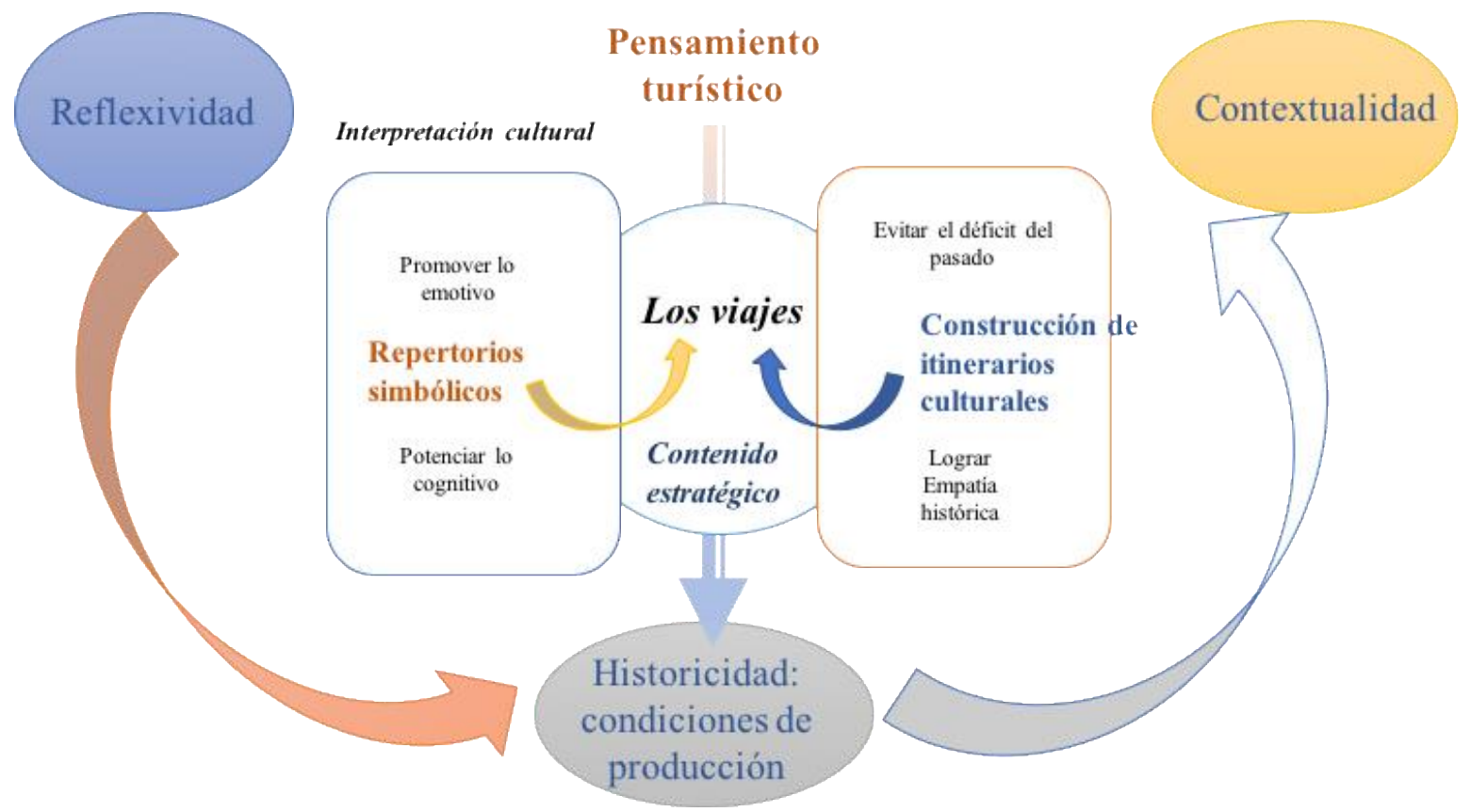

Ahora bien, las formas de articulación del viaje comprendido como un objeto de estudio relacionado con formas culturales e interculturales, entromete tres operaciones básicas de la interdisciplina para ganar profundidad y coherencia. La primera de ellas es el principio de reflexividad entendido como como la visibilidad de los sujetos invisibilizados que fueron desaparecidos bajo la lógica del sujeto objetivante neutral y objetivo. El segundo de ellos es la contextualidad que no se supedita a modelos sino a la lógica de construcción del propio pensamiento que a su vez está inmerso en regímenes representacionales. El tercero de ellos,

\footnotetext{
${ }^{18}$ Ver Serna Dimas A (2014) Testimonio, contingencia, archivo y permanencia. Oralidad, memoria y archivo en: cuestiones de derechos humanos, Revista esfera No 4
} 
es la historicidad que permite construir las condiciones producción y reproducción de los sistemas de pensamiento (Serna, A.; Oviedo. A. \& Bravo, F., 2010)

Finalmente, estas articulaciones permiten articular prácticas, repertorios simbólicos y diferentes producciones culturales vividas en un viaje como experiencia cultural. Se insiste en que el turismo no puede ser la única disciplina en arrogarse el derecho de conocer y estudiar el fenómeno del viaje. Más allá que existan subdisciplinas como la sociología del turismo, la geografía del turismo, la antropología del turismo entre otras, se requiere un debate más decidido de las ciencias sociales y humanas, no para demarcar a al turismo como una disciplina sometida a las reglas de las humanidades y los desarrollos del pensamiento social, sino para lograr potenciar el sentido del viaje y reconocer la existencia de culturas viajeras. Si bien esta apuesta supone un desafío en términos epistemológicos, también permite encontrar respuestas sobre la relación cada vez más directa entre los desarrollos disciplinares del turismo y las ciencias sociales para superar los tecnicismos y los reduccionismos a la que la experiencia cultural del viaje está sometida. Como ya se ha mencionado en la actualidad la construcción de rutas y guiones turísticos adolece de reflexiones profundas sobre la experiencia histórica y su relación con las diferentes versiones del pasado.

Para ganar mayor profundidad en la construcción de objetos turísticos, o si se prefiere objetos de estudio relativos al viaje como fenómeno histórico, social y cultural habría que involucrar criterios de legitimación de tipo epistemológico, ético y político que permita superar el plano logístico, instrumental y técnico con los cuales se asume la producción del objeto turístico.. Se insiste más en objeto turístico, que en producto turístico para lograr mayor participación de las ciencias sociales y humanas en la comprensión del fenómeno del viaje en sus relaciones con la difusión de los patrimonios culturales. Es en la misma construcción de los objetos turísticos donde se insiste en el contraste de posiciones frente a la comprensión del fenómeno turístico junto con la variedad de abordajes teóricos, metodológicos y vivenciales. 


\section{Referencias}

Acevedo, Ó. (2012). Geografías de la memoria: Posiciones de las víctimas en Colombia en el período de justicia transicional (2005-2010), Bogotá: Editorial Pontificia Universidad Javeriana, $119 \mathrm{p}$.

Araque,G \& Llano, F. (2018). El viaje y el recorrido como innovación educativa: El turismo de memoria y la didáctica del patrimonio como recursos educativos para enfrentar el posconflicto colombiano En: Experiencias en innovación educativa. ed: Bogota: Ediciones de la U, p.430 - 441 ,

Augé, M. (2008). El viaje imposible: el turismo y sus imágenes. Barcelona: Editorial Gedisa.

Avishai, M. (2000). Ética del recuerdo. Barcelona: Editorial Herder

Bourdieu P. (2014). Sobre el Estado cursos en el Collége de France (1989-1992). Barcelona: Anagrama.

Campodónico, R., \& Chalar, L. (2011). Hacia la construcción del conocimiento en turismo. Estudios y perspectivas en turismo, 20(6).

Casterás, R. (s.f). Las juventudes comunistas ibéricas del POUM. Recuperado de $\underline{\text { https://gredos.usal.es/jspui/bitstream/10366/79989/1/Las_Juventudes_Comunistas_Iber }}$ icas_del_P.pdf

Clifford, J. (1995). Las culturas del viaje en: Revista de Occidente, No. 170-171, 45-74.

Colllingwood, E. (2009). El filo fotográfico de la historia. Walter Benjamín y el olvido de lo inolvidable. Chile: Ediciones metales pesados, Consejo Nacional de la Cultura y las artes, gobierno de Chile 
Chavarro, C. \& Llano, F. (2010). El héroe, el lujo y la precariedad patrimonio histórico en Bogotá (1880-1950). Bogotá: Universidad La Gran Colombia.

Folgado, J.; Oliveira, P. \& Hernández, J. (2011). Imagen del destino y marca turística: sinergias e implicaciones. Tourism \& Management Studies. Volumen 1, 904-914.

García, N. (1994). El porvenir del pasado. En Culturas híbridas. Estrategias para entrar y salir de la modernidad. México: editorial Sudamericana149-190

González, I. (2015). Patrimonio cultural conceptos, debates y problemas. España: Cátedra

Hernández, J. (2015). El turismo como objeto de estudio: análisis de la producción bibliográfica de los antropólogos españoles del turismo. Pasos, Revista de turismo y patrimonio cultural 13(2): 305-331.

Ibagón, J. (2016). Entre ausencias y presencias ausentes. Los textos escolares y el lugar de lo negro en la enseñanza de la historia de colombia 1991-2013. Bogotá: Editorial Pontificia Universidad Javeriana.

Jafari, J. (2005). El turismo como disciplina científica. Revista política y sociedad. Volumen 42 (1), 12-19.

Baudrillard, J.(1977). Cultura y simulacro Traducido por Pedro Rovira Barcelona: Editorial Kairós,

Llano, F. (2017). Gastronomía, turismo y potencialidades territoriales: el plato minero y la salazón, bases para el turismo alimentario en Nemocón. Cuadernos de Geografía: Revista Colombiana de Geografía. Volumen 26 (2), 295-306.

Organización Mundial del Trabajo OMT (2018). Panorama OMT del turismo internacional. Recuperado de https://www.e-unwto.org/doi/pdf/10.18111/9789284419890 
Pérez T, (2001). Conflicto y posconflicto: una mirada a la política de seguridad democrática. Separata humanística, volumen 5 (10). Recuperado de dehttp://dialnet.unirioja.es/servlet/articulo.

Roch, L. (2001). Ciencia, discurso y narración en la historia: ¿incompatibilidad epistemológica y coexistencia necesaria? En: Litterae. Revista de la asociación de exalumnos del seminario Andrés Bello No. 9 imprenta patriótica del instituto Caro y Cuervo febrero

Sánchez -Biosca,V. (2004). Equivocas sombras de Auschwitz en vigencia y singularidad de Auschwitz un acontecimiento histórico que nos da que pensar. Revista Anthropos huellas del conocimiento. Volumen 1 (2), 35-37.

Sánchez, P. (2014). Turismo, emprendimiento y la privatización de las políticas culturales en Colombia En: El valor del patrimonio: mercado, políticas culturales y agenciamientos sociales (comp. Chaves.; Montenegro. \& Zambrano, M.).Colombia: colección Antropología de la modernidad Instituto Colombiano de Antropología e Historia

Serna, A. (2001). Próceres, textos y monumentos: culturas urbanas, discursos escolares y formas de la historia: Bogotá (1938- 1991) Bogotá: Univ. Del bosque Facultad de Educación.

Serna, A. (2012). Memoria y creencia: una mirada políticamente incorrecta a ciertas vindicaciones de la memoria En: Las víctimas: entre la memoria y el olvido (Edit García, R.; Jiménez, A. \& Becerra, J.). Bogotá: Editorial Universidad Distrital Francisco José de Caldas.

Serna, A.; Oviedo. A. \& Bravo, F. (2010). Creencia, sistema de creencias y poder simbólico. Una propuesta para indagar los sistemas ideacionales desde la investigación social interdisciplinaria En: Desafios en estudios sociales e interdisciplinariedad (comp Piedrahita,C. \& Jiménez, A.). Bogotá: Universidad Distrital Francisco José de Caldas. $135-153$ 
Serna, D. A. (2006). Identidad ciudadana, lenguajes coloniales y conflicto social. In S. D. A. Cifuentes María Teresa (Ed.). Ciudadanía y conflicto, Memorias del seminario internacional. Bogotá: Universidad Distrital Francisco José de Caldas. 167-182

Steiner George. (2006). En el castillo de Barba Azul. Aproximacion a un nuevo concepto de cultura. Sevilla: Editorial Gedisa.

Yory, C. (2006). Ciudad, consumo y Globalización. Bogotá: Editorial Pontificia Universidad Javeriana, Colección Biblioteca Personal 